\title{
Physicochemical composition and antioxidant activity of several pomegranate (Punica granatum L.) cultivars grown in Spain
}

\author{
Luana Fernandes ${ }^{1} \cdot$ José Alberto Pereira $^{1}$ - Isabel Lopéz-Cortés ${ }^{2}$. \\ Domingo M. Salazar ${ }^{2}$ Julia González-Álvarez ${ }^{3} \cdot$ Elsa Ramalhosa $^{1}$
}

Received: 19 January 2017 / Revised: 13 March 2017 / Accepted: 25 March 2017 / Published online: 8 April 2017

(C) Springer-Verlag Berlin Heidelberg 2017

\begin{abstract}
Nine pomegranate cultivars grown in Spain were selected, and their physicochemical (total soluble solids, $\mathrm{pH}$, titratable acidity, maturity index, monomeric anthocyanin pigment, flavonoids, hydrolyzable tannins, and vitamin C) and antioxidant properties and polyphenolic composition of the juices were compared. A total of 53 polyphenols were identified, showing cultivars different profiles. Of all nine cultivars, Katirbasi had the highest contents of flavonoids, hydrolyzable tannins and vitamin $\mathrm{C}$, as well as gallic acid and ellagic acid contents, explaining its high total reducing capacity. Principal component analysis allowed Katirbasi to be differentiated clearly from the others. Other cultivars presented also interesting characteristics such as high monomeric anthocyanin pigment content (CG8 cultivar) and interesting antioxidant activity (Wonderful 2 and CG8 cultivars). CG8 was the cultivar with the highest value of cyanidin-3,5-di- $O$-glucoside. Thus, this study will assist pomegranate producers in choosing the most suitable cultivar according to its ultimate use.
\end{abstract}

Keywords Punica granatum L. C Cultivars · Juice · Physicochemical properties - Antioxidant activity . Polyphenolic composition

Elsa Ramalhosa

elsa@ipb.pt

1 Mountain Research Centre (CIMO)/School of Agriculture, Polytechnic Institute of Bragança, Campus de Santa Apolónia, 5300-253 Bragança, Portugal

2 Vegetable Production Department, Polytechnic University of Valencia, Camino de Vera s/n, 46022 Valencia, Spain

3 Department of Chemical Engineering, School of Engineering, University of Santiago de Compostela, Rúa Lope Gomez de Marzoa s/n 15782, Santiago de Compostela, Spain

\section{Introduction}

Spain is the greatest European producer of pomegranate, being its production mainly located in Valencia provinces, namely: Alicante, Valencia and Castellón [1]. Forty Spanish cultivars have been reported in the literature so far [2]. Mollar de Elche and Valenciana are the most widely spread cultivars in Spain, displaying very attractive sensorial characteristics [3].

The edible parts of pomegranate fruit (about $50 \%$ of total fruit weight) comprise $80 \%$ juice and $20 \%$ seeds. Generally, fresh juice contains $85 \%$ water, $10 \%$ total sugars, and $1.5 \%$ pectin, ascorbic acid, and polyphenolic flavonoids [4]. Pomegranate juice have market potential [5] because it is a source of many valuable substances such as hydrolyzable tannins (punicalagins and punicalins), condensed tannins, anthocyanins, phenolic (gallic acid and ellagic acid) and organic acids (malic acid), as well as, numerous minerals, particularly iron [3, 4, 6-12]. Some of these compounds may contribute to health-promoting effects, namely protection against cancer, cardiovascular disease, diabetes, obesity, inflammations, erectile dysfunction, bacterial infections, antibiotic resistance, UV-induced skin damage, infant brain ischemia, male infertility, Alzheimer's disease, and arthritis[4, 8, 13-20]. Pomegranate juice can be used in beverage formulations, such as juices, carbonated drinks, syrups, liqueurs, and fermented products [21-23], as well as, in jellies, as flavoring and coloring agents and in dietetic and prophylactic treatments [24]. Moreover, many pomegranate supplements have been produced and analyzed [25]. Some studies have been performed in pomegranate juices, concerning their physicochemical characterization, antioxidant activity, and/or polyphenolic composition. Those studies have focused in Iranian [26, 27], Turkish 
[28, 29], Croatian [30, 31], Moroccan [32], and Italian [33] pomegranate cultivars. Regarding Spanish cultivars, some works have also been made, being the cultivars studied until now the following: Mollar de Elche, Piñón Tierno de Ojós, Casta del Reino de Ojós, Borde de Albatera, Borde de Orihuela, Borde de Beniel, Valenciana and Wonderful [10-12, 32-37]. Nevertheless, much more pomegranate cultivars are grown in Spain whose potential is not well known.

So, the present study aims to physicochemically characterize, evaluate the antioxidant activity, identify and quantify the main polyphenolic compounds (HPLC-DAD$\mathrm{MS} / \mathrm{ESI}$ ) present in the juices of nine cultivars grown in Spain. Five of these cultivars had not been studied until now. Thus, this study will allow the comparison between these cultivars and to increase the available information on the less known pomegranate cultivars grown in Spain for further valorisation and development of new pomegranate based products.

\section{Materials and methods}

\section{Solvents and reagents}

All reagents and solvents were of analytical or HPLC grade. The Folin-Ciocalteu reagent, sodium hydroxide, potassium chloride, and sodium acetate were purchased from Panreac AppliChem (Barcelona, Spain). Potassium ferricyanide (III), potassium iodate, quercetin, tannic acid, gallic acid, 2,2-diphenyl-1-picrylhydrazyl, and iron (III) chloride were obtained from Sigma-Aldrich (St. Louis, MO, USA). Trichloroacetic acid, methanol, hydrochloric acid, aluminum chloride, and sodium nitrate were purchased from Fisher Scientific (Leicestershire, UK), and sodium dihydrogen phosphate monohydrate and di-sodium hydrogen phosphate dehydrate from Scharlau (Sentmenat, Spain). Solvents used for HPLC-DAD-ESI/MS separation and identification were purchased from Sigma-Aldrich (St. Louis, MO, USA). A Milli-Q water purification system (Millipore, Molsheim, France) was used to obtain ultrapure water (resistivity of $18.2 \mathrm{M} \Omega \mathrm{cm}$ ) for quantitative analysis.

\section{Pomegranate samples}

The fruits were collected from adult trees ( $\cong 16$ year-old) located in Elche-Alicante (Spain) in an area of 2.5 ha. The trees are planted in a $3.5 \times 3$ plantation frame with a controlled deficit irrigation (33\% of the crop evapotranspiration $(\mathrm{ETc})$ ), with water conductivity of $5.1 \mathrm{mS}$. The soil is white loamy, limestone soil (22.2\% active limestone) and $0.9 \%$ organic matter, with a cation exchange capacity of $10 \mathrm{meq} / 100 \mathrm{~g}$. The cultivation practice on orchard was based on organic production of agricultural products according Council Regulation (EEC) No 2092/91 of 24 June 1991 [38]. The pomegranates studied in this work were harvested in Valencia, Spain, at their high ripening stage (included pomegranates with reddish skin color). The selected ripening stage corresponded to the Biologische Bundesantalt Bundessortenamt and Chemical (BBCH) 85 stage, according to Meier [39] and Melgarejo and Salazar [40]. Nine cultivars were selected, namely: Mollar de Elche, Valenciana, White, CG8, Cis 127, Parfianka, Katirbasi, Wonderful 1 and Wonderful 2 (Fig. 1a). Wonderful 1 and 2 are clones, namely: Wonderful 1 is the clone 100-1 whose origin is Israel and Wonderful 2 is the clone WG from Davis (California).Three lots of samples were made, each containing three fruits, collected from different trees in the same experimental field. Each lot was analyzed in duplicate. The fruits were transported to the laboratory under refrigeration conditions. Then, each pomegranate was manually separated into its components, namely arils, skin, and pellicle. The juice was extracted by squeezing the seeds without crushing them, and stored frozen $\left(-23{ }^{\circ} \mathrm{C}\right)$ for further analysis.

\section{Physical characteristics, total soluble solids, $\mathbf{p H}$, total titratable acidity, and maturity index}

The following parameters were evaluated in the nine pomegranate cultivars: weights of the fruits, skin, pellicles, and arils. According to Codex Alimentarius Commission [41], pomegranate may be sized by weight (individual weight of each fruit) and classified from $A(\geq 501 \mathrm{~g})$ to E (125-200 g) size codes. The content of total soluble solids (TSS) and $\mathrm{pH}$ of pomegranate juices were obtained by measuring the ${ }^{\circ}$ Brix of juices in a Abbe refractometer (Optic Ivymen System, Madrid, Spain) and the $\mathrm{pH}$ value in a potentiometer (370 pH meter of Jenway, Essex, England), respectively. Total titratable acidity (TA) was determined in $2 \mathrm{ml}$ juice mixed with $10 \mathrm{ml}$ ultra-pure water and titrated with $0.1 \mathrm{~N}$ $\mathrm{NaOH}$ to $\mathrm{pH} 8.2[42,43]$. TA was expressed as percentage of citric acid. For each sample the measurements were made in duplicate. The maturity index (MI) was determined by the ratio TSS/TA, as suggested by Martínez et al. [36]. Melgarejo et al. [44] proposed that Spanish pomegranate cultivars could be classified according to their MI values as follow: sweet: $\mathrm{MI}=31-98$; sour-sweet: $\mathrm{MI}=17-24$; and sour: $\mathrm{MI}=5-8$.

\section{Total monomeric anthocyanin}

The total monomeric anthocyanin contents in the pomegranate juices were estimated by the $\mathrm{pH}$ differential method, following the methodologies used by Bchir et al. 
Fig. 1 Pomegranate fruits (a) and juices (b) of nine cultivars grown in Spain: 1-Mollar de Elche, 2-Valenciana, 3White, 4-CG8, 5-Cis 127, 6-Katirbasi, 7-Parfianka, 8Wonderful 1, 9-Wonderful 2

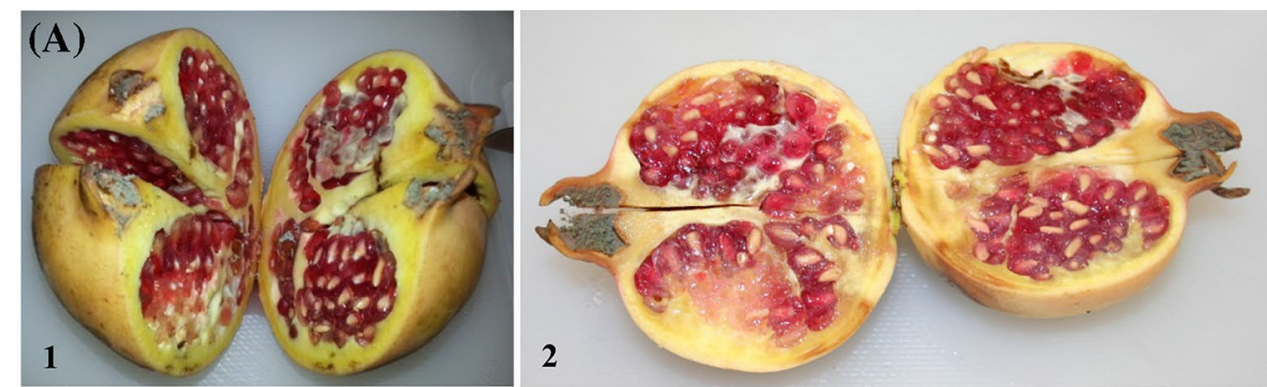

3
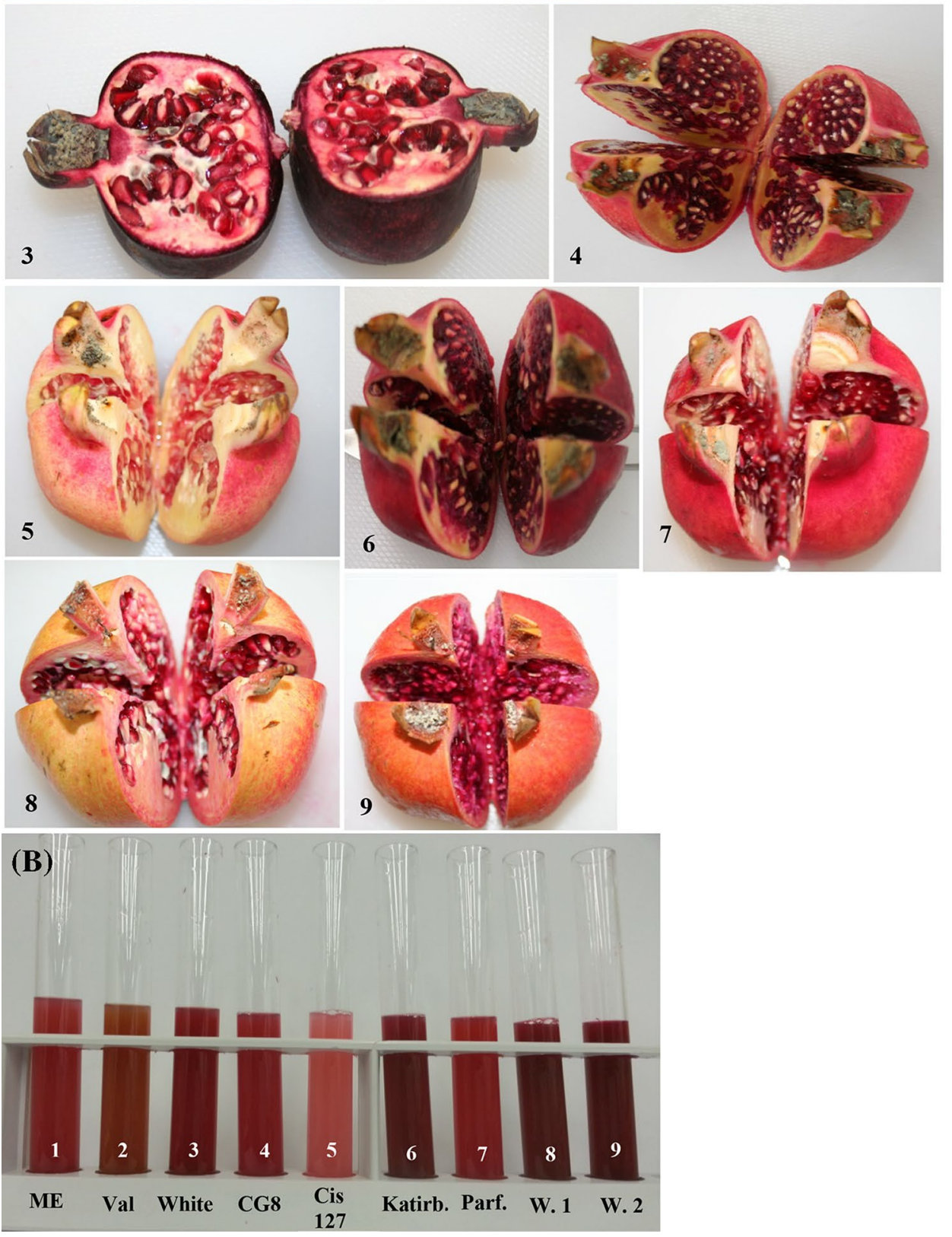

[45] and Rajasekar et al. [46]. The method consisted in using two buffer systems: potassium chloride buffer at $\mathrm{pH} 1.0(0.025 \mathrm{M})$ and sodium acetate at $\mathrm{pH} 4.5(0.4 \mathrm{M})$. $250 \mu \mathrm{l}$ of juice was diluted with $\mathrm{pH} 1.0$ and $\mathrm{pH} 4.5$ buffers in $25 \mathrm{ml}$ flasks and allowed to stand for $30 \mathrm{~min}$ at room temperature. Subsequently, the absorbance readings were made on a UV-visible spectrophotometer (Thermo, Genesys $10 \mathrm{UV}$, Waltham, USA) at the wavelengths of 510 and $700 \mathrm{~nm}$, being $A$ determined by the equation: $A=\left(A_{510 \mathrm{~nm}}-A_{700 \mathrm{~nm}}\right){ }_{\mathrm{pH} 1.0}-\left(A_{510 \mathrm{~nm}}-A_{700 \mathrm{~nm}}\right) \mathrm{pH} 4.5$. The 
monomeric anthocyanin pigment concentration was calculated as cyanidin-3-glucoside, being the concentration determined by the equation: Monomeric anthocyanin pigment $(\mathrm{mg} \mathrm{Cy} 3$-glu/l) $=A \times \mathrm{MW} \times \mathrm{DF} \times 1000 /(\varepsilon \times 1)$, where $A=$ absorbance difference, $\mathrm{MW}=$ molecular weight (449.2), DF $=$ dilution factor, and $\varepsilon=$ molar absorptivity $(26,900)$. All measurements were performed in duplicate.

\section{Flavonoids}

The total flavonoid content was determined by the method described by Viuda-Martos et al. [12], with slight modifications. One $\mathrm{ml}$ of juice solutions at different concentrations were mixed with $0.3 \mathrm{ml}$ of $\mathrm{NaNO}_{2}(5 \%, \mathrm{~m} / \mathrm{v})$. After $5 \mathrm{~min}$, $0.3 \mathrm{ml}$ of $\mathrm{AlCl}_{3}(10 \%, \mathrm{~m} / \mathrm{v})$ were mixed. After $6 \mathrm{~min}, 2 \mathrm{ml}$ of $\mathrm{NaOH}(1 \mathrm{M})$ were added. The absorbance was read at $510 \mathrm{~nm}$ and flavonoids were quantified using a standard curve of quercetin $(10-160 \mu \mathrm{g} / \mathrm{ml})$. The results were expressed in mg quercetin equivalents per $100 \mathrm{ml}$ juice ( $\mathrm{mg}$ QE/100 ml juice).

\section{Hydrolyzable tannins}

The content of hydrolyzable tannins was determined by the method described by Elfalleh et al. [47]. To different concentrations of juice $(1 \mathrm{ml}), 5 \mathrm{ml}$ of $2.5 \% \mathrm{KIO}_{3}$ was added and stirred for $10 \mathrm{~s}$. The absorbance was measured at $550 \mathrm{~nm}$. The blank was made with methanol/water (4:1, $\mathrm{v} / \mathrm{v})$. Different concentrations of tannic acid solutions $(0.025-1.6 \mathrm{~g} / \mathrm{l})$ were used for calibration. Results were expressed in $\mathrm{mg}$ of tannic acid equivalent per $100 \mathrm{ml}$ juice (mg TAE/100 ml juice).

\section{Vitamin C}

Vitamin C (ascorbic acid) content was determined by redox titration using iodine. In an Erlenmeyer flask, $2 \mathrm{ml}$ of pomegranate juice were mixed with $18 \mathrm{ml}$ of water and five drops of starch solution. The mixture was titrated with a standardized iodine solution. Results of vitamin C content were expressed as $\mathrm{mg}$ ascorbic acid per $100 \mathrm{ml}$ juice (mg AA/100 ml juice).

\section{Antioxidant activity}

\section{Total reducing capacity}

The total reducing capacity of each sample was determined by the Folin-Ciocalteu method, described by Falcão et al. [48]. To $100 \mu 1$ of juice solutions, $7.90 \mathrm{ml}$ of deionized water and $500 \mu 1$ of Folin-Ciocalteu reagent were added. The blank and standards were prepared similarly, replacing the sample by methanol and standard, respectively. After
3-8 $\mathrm{min}, 1.5 \mathrm{ml}$ of saturated sodium carbonate solution was added. After $2 \mathrm{~h}$ the absorbance values were read at $765 \mathrm{~nm}$. A calibration curve was obtained with gallic acid $(0.25-5 \mathrm{mg} / \mathrm{l})$, and the results expressed on $\mathrm{mg}$ gallic acid equivalent per $100 \mathrm{ml}$ juice (mg GAE/100 ml juice).

DPPH (2,2-diphenyl-1-picrylhydrazyl) radical-scavenging activity

DPPH radical-scavenging activity was determined by the procedure described by Delgado et al. [49], with some modifications. $0.0024 \mathrm{~g}$ of DPPH was dissolved in $100 \mathrm{ml}$ of methanol to obtain a solution $6.09 \times 10^{-5} \mathrm{~mol} / \mathrm{l}$. For each cultivar, different juice solutions were prepared in methanol:water $(4: 1, \mathrm{v} / \mathrm{v})$ and $300 \mu \mathrm{l}$ of these solutions were added to $2.7 \mathrm{ml}$ of DPPH methanolic solution. After $1 \mathrm{~h}$ in the dark at room temperature, the absorbance was determined at $517 \mathrm{~nm}$. Antioxidant activity was expressed by the percentage of scavenging effect according to the formula in Eq. 1:

DPPH radical - scavenging effect $(\%)=\frac{A_{\mathrm{DPPH}}-A_{\text {Sample }}}{A_{\mathrm{DPPH}}} \times 100$

$A_{\mathrm{DPPH}}$ was the absorbance of the DPPH solution and $A_{\text {Sam- }}$ ple the absorbance in the presence of the sample. The blank was made with methanol/water. The $\mathrm{EC}_{50}$ values corresponded to the juice concentration with a DPPH radicalscavenging effect of $50 \%$.

\section{Reducing power}

The reducing power values of the juices were determined by the procedure described by Delgado et al. [49]. To $1.0 \mathrm{ml}$ of the juice solutions at different concentrations were added $2.5 \mathrm{ml}$ of phosphate buffer $0.2 \mathrm{M}(\mathrm{pH} \mathrm{6.6)}$ and $2.5 \mathrm{ml}$ of $\mathrm{K}_{3}\left[\mathrm{Fe}(\mathrm{CN})_{6}\right] 1 \%$ (w/v). After shaking, the mixture was incubated at $50{ }^{\circ} \mathrm{C}$ for $20 \mathrm{~min} .2 .5 \mathrm{ml}$ of $10 \%$ trichloroacetic acid (w/v) was added with further stirring. A volume of $2.5 \mathrm{ml}$ of the mixture was transferred to another test tube, to which were added $2.5 \mathrm{ml}$ of distilled water and $0.5 \mathrm{ml}$ of $\mathrm{FeCl}_{3} 0.1 \%$ (w/v). The absorbance values were read at $700 \mathrm{~nm}$. From the graph $\mathrm{Abs}_{700 \mathrm{~nm}}$ versus solution concentration, the $\mathrm{EC}_{50}$ values were determined corresponding to the concentration with an absorbance of 0.5.

\section{HPLC-ESI-MS (qualitative) and HPLC-ESI-MS/MS (quantitative) techniques and conditions}

The juices were analyzed according to the method described by Gil et al. [6] with slight modifications. Phenolic compounds were characterized using a HPLC 1200 series from Agilent (Waldbronn, Germany), equipped with an autosampler, a pump, a Zorbax Eclipse XDB C18 
column $(4.6 \times 150 \mathrm{~mm}, 5 \mu \mathrm{m})$ and a diode array detector (Agilent G1315C). This HPLC system was connected in series with an Agilent 6410B triple quadrupole mass spectrometer (MS) (Waldbronn, Germany) fitted with an ESI source.

The HPLC mobile phase consisted of $2.5 \%(\mathrm{v} / \mathrm{v})$ acetic acid in water (eluent $\mathrm{A})$ and $2.5 \%(\mathrm{v} / \mathrm{v})$ acetic acid in methanol (eluent B). The flow rate was $1 \mathrm{ml} / \mathrm{min}$, and the gradient profile was the following: $5-15 \%$ B (15 min), $15-30 \%$ B (35 min), 30-40\% B (40 min), 40-60\% B (50 min), 60-90\% B (55 min), and $100 \% \mathrm{~B}$ isocratic $(75 \mathrm{~min})$. Total run time was $75 \mathrm{~min}$. The injection volume for all samples was $20 \mu \mathrm{L}$. The diode array detector was set at 280,360 , and $520 \mathrm{~nm}$.

The LC eluate was introduced directly into the ESI interface without splitting at a flow rate of $1 \mathrm{ml} / \mathrm{min}$ and the phenolic compounds were analyzed in negative ionization mode and anthocyanins in positive ionization mode. The temperature of the nebulizing gas was $350{ }^{\circ} \mathrm{C}$ at a pressure of $35 \mathrm{psi}$. The flow rate of the gas was $10 \mathrm{l} /$ $\mathrm{min}$ and the capillary voltage of $4000 \mathrm{~V}$. Analyses were carried out using full scan from m/z 100 to 1600 . Compounds identification was performed by their molecular weights, taking into account the data reported by Mena et al. [50] and Calani et al. [51]. Aditionally, gallic acid, ellagic acid, cyanidin-3,5-di- $O$-glucoside, cyanidin, 3-O-glucoside and pelargonidin-3-O-glucoside chloride were quantified using standard solutions by HPLC-ESI-MS/MS.

\section{Statistical analysis}

SPSS Statistic software, version 18.0 (SPSS Inc., Chicago, USA), was used for the statistical treatment of the data. Normality and homogeneity of variance were tested by Shapiro-Wilk and Levene's tests, respectively. Analysis of variance (one-way ANOVA) or ANOVA Welch was carried out to evaluate if there were significant differences $(p<0.05)$ between samples. Additionally, significant post hoc analyses were performed (Tukey HSD test if variances in the different groups were identical or Games-Howell test if they were not). The correlations between variables were determined by Pearson correlation coefficient.

A principal component analysis (PCA) was also performed to total reducing capacity, hydrolyzable tannins, flavonoids, vitamin $\mathrm{C}$, anthocyanin, and $\mathrm{EC}_{50}$ values of DPPH and reducing power assays of the nine pomegranate cultivars. The PCA score plot was used to differentiate them.

\section{Results and discussion}

\section{Physical characteristics}

The weights of the nine pomegranate cultivars grown in Spain, as well as of their constituents (skin, pellicle, arils and seeds), are presented in Table 1. Mollar de Elche cultivar had the heaviest fruits $(478.64 \mathrm{~g})$ unlike White that presented the lowest $(175.95 \mathrm{~g})$. Regarding Mollar de Elche cultivar, our results were higher than reported by Martínez et al. [36] of $251.05 \mathrm{~g}$ for ME15 cultivar to $261.72 \mathrm{~g}$ for ME14, as well as, Legua et al. [35] who obtained $280.58 \mathrm{~g}$ for ME5 cultivar to $351.48 \mathrm{~g}$ for ME16, indicating that our Mollar de Elche cultivar presented bigger fruits than those studied by the authors mentioned. In other studies of different pomegranate cultivars the fruit weight was similar to ours, ranging from 189.4 to $595.9 \mathrm{~g}$ in Croatia [52], and between 173.5 and $622.3 \mathrm{~g}$ in Italy [33, 53], while Tehranifar et al. [26] found lowest values, between 197 and $315 \mathrm{~g}$.

When taking into account the classification of the Codex Alimentarius Commission [41], it was detected that the nine cultivars had different size codes; however, most of them were classified in B (401-500 g) and C (301-400 g) size codes, except Katirbasi (D) and White (E) cultivars that presented the smallest fruits. White cultivar showed the lowest values for the four component weights (skin-78.27 g; pellicles-3.31 g; arils$89.05 \mathrm{~g}$ and seeds $-16.83 \mathrm{~g}$ ). The skin percentage ranged between $36.18 \%$ for Parfianka and $57.74 \%$ for Cis 127 . Arils (edible part) were the other major component of pomegranates, representing $49.40 \%$ (Cis 127) to $59.68 \%$ (Parfianka) of the fruit. Finally, the seed percentage varied from 6.01 to $10.65 \%$ of fruit weight for Mollar de Elche and Wonderful 1, respectively, as well as from 11.51 to $21.47 \%$ of arils weights for the same cultivars. In this order, Mollar de Elche had the highest juice yield due to its high arils weight and low percentage of seeds, indicating to be the most appropriate for juice industry.

\section{TSS, pH, TA, and maturity index}

Table 2 shows that significant differences $(p<0.05)$ among the nine cultivars were observed for TSS contents, varying between 14.87 and $18.04{ }^{\circ}$ Brix for Parfianka and Wonderful 1 cultivars, respectively. When comparing this range with other authors, who also studied cultivars grown in Spain, including Mollar de Elche (ME), Valenciana $(\mathrm{V})$, and Wonderful $(\mathrm{W})$ beyond others, our range was quite similar. Melgarejo et al. [44] reported TSS contents between $14.31(\mathrm{CRO} 2)$ and $15.81{ }^{\circ} \mathrm{Brix}$ (ME2); Melgarejo et al. [54] of 11.94 (CRO2) to 14.84 


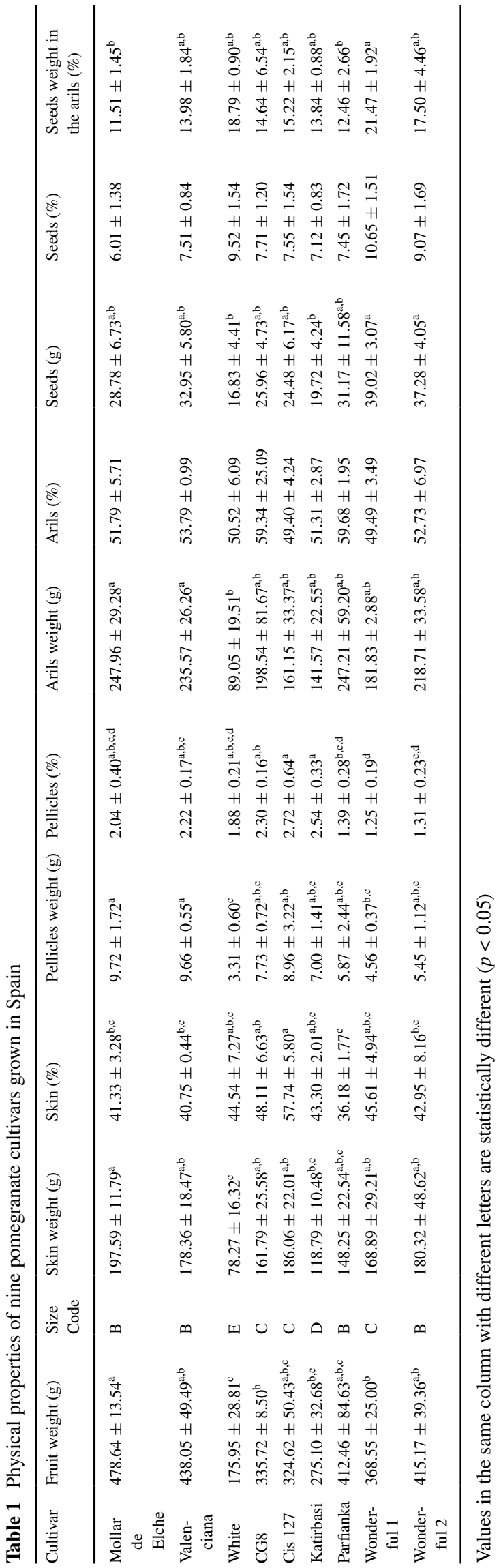

${ }^{\circ}$ Brix (BA1); Martínez et al. [36] of 12.36 (ME14) and $16.32{ }^{\circ}$ Brix (PTO7); Mena et al. [3] of 13.73 (V.111) to 17.60 (WSN); and Legua et al. [35] of 14.79 (ME17) to 15.81 (MO6). Our results showed that there is one cultivar significantly sweeter than Mollar de Elche (the best known by consumers), namely Wonderful 1; however, as previously mentioned, this cultivar had one of the lowest arils percentage $(49.49 \%)$ and the highest seed percentage $(10.65 \%)$, making it less appreciated and chosen by the consumers and juice industry.

Regarding $\mathrm{pH}$ values (Table 2), significant differences between cultivars were found, ranging from 2.56 (Wonderful 2) to 4.31 (Valenciana). US Food and Drug Administration [55] reported a $\mathrm{pH}$ range of 2.93-3.20 for the edible portions (arils) of pomegranate in the natural state. In our study, Cis 127 and Wonderful 1 were the only cultivars that showed values within that range, presenting the other cultivars higher $\mathrm{pH}$ values, with the exception of Parfianka and Wonderful 2. These had $\mathrm{pH}$ values lower than the range referred, indicating to be the most acid. Nevertheless, after comparing our results with other authors who had studied different cultivars, similar $\mathrm{pH}$ ranges were found. Tehranifar et al. [26] determined $\mathrm{pH}$ values between 3.16 and 4.09; Gadže et al. [30] of 2.9 and 4.0; Ozgen et al. [29] of 2.98 and 3.68; Ferrara et al. [33] of 2.93 and 3.59; Legua et al. [35] of 3.94 and 4.07; Raduníc et al. [52] of 2.81-3.90; and Melgarejo-Sánchez et al. [56] of 3.49 and 5.14. Several factors such as fruit variety, maturity status, and postharvest handling will contribute to differences in $\mathrm{pH}$ values [57]. Regarding Mollar de Elche cultivar, Melgarejo et al. $[44,54]$ obtained similar $\mathrm{pH}$ values to our (3.97) for several clones from 3.96 (ME12) to 4.27 (ME1), and 4.06 (ME2) to 4.11 (ME14), respectively. Identical pH values were also obtained by Martínez et al. [36] (4.28 for ME14 and ME15); Mena et al. [3] (3.84 for M.29-4.00 for M.Leon.1); and Legua et al. [35] (3.99 for ME16 and 4.07 for ME5). Concerning Valenciana cultivar, our result (4.31) was higher than Mena et al. [3], 3.60 for V.1113.67 for V.46i, indicating that our cultivar had lower acidity than those. On the other hand, when comparing our results of Wonderful 1 and 2 cultivars (2.97 and 2.56, respectively) with Mena et al. [3] (2.52 for W.7-3.71 for W.2), similar results were obtained. Nevertheless, some of these physicochemical parameters had different values than ours because arils' juices were prepared in different ways, namely: using a commercial/domestic blender [29, $30,35,36,44,57]$, making pressure on the arils against a nylon mesh $[3,56]$ or through layers of cheesecloth [52].The organic acids present in the arils of pomegranate include, mainly, citric, malic, oxalic, acetic, fumaric, and tartaric acids [10]. According to Mars et al. [58] cited by Pavez [54], pomegranate cultivars can be classified 
Table 2 TSS, pH, TA, and maturity indexes of juices of nine pomegranate cultivars grown in Spain

\begin{tabular}{llllll}
\hline Cultivar & $\begin{array}{l}\text { TSS } \\
\left({ }^{\circ} \text { Brix }\right)\end{array}$ & pH & $\begin{array}{l}\text { TA } \\
(\% \text { citric acid)* }\end{array}$ & $\begin{array}{l}\text { TSS/TA } \\
\left({ }^{\circ} \text { Brix/ \% citric acid) }\right.\end{array}$ & Maturity index \\
\hline Mollar de Elche & $15.84 \pm 0.06^{\mathrm{b}, \mathrm{c}, \mathrm{d}}$ & $3.97 \pm 0.05^{\mathrm{b}}$ & $0.32 \pm 0.01^{\mathrm{d}, \mathrm{e}}$ (Sweet) & 49.18 & Sweet \\
Valenciana & $16.37 \pm 0.01^{\mathrm{b}, \mathrm{c}}$ & $4.31 \pm 0.03^{\mathrm{a}}$ & $0.28 \pm 0.01^{\mathrm{e}}$ (Sweet) & 57.73 & Sweet \\
White & $15.70 \pm 0.29^{\mathrm{b}, \mathrm{c}, \mathrm{d}}$ & $3.45 \pm 0.01^{\mathrm{d}}$ & $0.60 \pm 0.07^{\mathrm{c}}$ (Sweet) & 26.06 & Sour-sweet to Sweet \\
CG8 & $15.87 \pm 0.87^{\mathrm{b}, \mathrm{c}, \mathrm{d}}$ & $3.57 \pm 0.01^{\mathrm{c}}$ & $0.74 \pm 0.02^{\mathrm{c}}$ Sweet) & 21.41 & Sour-Sweet \\
Cis 127 & $16.87 \pm 0.50^{\mathrm{a}, \mathrm{b}}$ & $3.03 \pm 0.04^{\mathrm{e}}$ & $0.52 \pm 0.05^{\mathrm{c}, \mathrm{d}}$ (Sweet) & 32.28 & Sweet \\
Katirbasi & $16.04 \pm 0.29^{\mathrm{b}, \mathrm{c}, \mathrm{d}}$ & $3.42 \pm 0.02^{\mathrm{d}}$ & $0.60 \pm 0.07^{\mathrm{c}}$ (Sweet) & 26.79 & Sour-Sweet to Sweet \\
Parfianka & $14.87 \pm 0.50^{\mathrm{d}}$ & $2.74 \pm 0.02^{\mathrm{f}}$ & $2.11 \pm 0.06^{\mathrm{b}}$ (Sour) & 7.04 & Sour \\
Wonderful 1 & $18.04 \pm 0.50^{\mathrm{a}}$ & $2.97 \pm 0.04^{\mathrm{e}}$ & $1.92 \pm 0.08^{\mathrm{b}}$ (Sour-Sweet) & 9.40 & Sour (a little higher than the limit) \\
Wonderful 2 & $15.20 \pm 0.29^{\mathrm{c}, \mathrm{d}}$ & $2.56 \pm 0.02^{\mathrm{g}}$ & $2.68 \pm 0.18^{\mathrm{a}}$ (Sour) & 5.68 & Sour \\
\hline
\end{tabular}

TSS Total soluble solids, TA total titratable acidity, TSS/TA maturity index

Values in the same column with different letters are statistically different $(p<0.05)$

* The values in parenthesis corresponded to juice acidity, taking into account the classification proposed by Mars et al. (1997)

by juice acidity (expressed as citric acid percentage) in sweet, sour-sweet and sour. Sweet cultivars have acidity lower than $0.9 \%$ and are mainly destined for fresh consumption. Sour-sweet cultivars have acidity between 1 and $2 \%$ and are used for the production of soft drinks. However, the ratio of sugars/acids is very important for human consumption and different ratios may be appreciated by people in different countries. Sour cultivars have acidity higher than $2 \%$ and may be used by the food industry for acid extraction (De Palma and Novello [59], cited by Pavez [60]). In this order, the majority of our cultivars were sweet and suitable for fresh consumption, with the exception of Parfianka (2.11\%) and Wonderful $2(2.68 \%)$ that were sour and Wonderful $1(1.92 \%)$ that was sour-sweet. The TA value of our Mollar de Elche $(0.32 \%)$ cultivar was slightly higher than those reported for other Mollar de Elche clones. For example, Melgarejo et al. [44, 54] obtained values between $0.20 \%$ (ME11) and $0.25 \%$ (ME14), and $0.24 \%$ (ME1) and $0.25 \%$ (ME2 and ME14), respectively, as well as Martínez et al. [36] of $0.26 \%$ (ME15) to $0.27 \%$ (ME14) and Legua et al. [35] of $0.23 \%$ (ME17) to $0.26 \%$ (ME5).

Concerning the maturity index (TSS/TA) and according to the classification suggested by Melgarejo et al. [44] for Spanish cultivars, our Mollar de Elche, Valenciana and Cis 127 were sweet, whereas Parfianka, Wonderful 1 and Wonderful 2 were sour. This was in line with the previous results on juice acidity. The other cultivars had intermediate maturity indexes. In generally, our result for Mollar de Elche (49.18) was lower than Melgarejo et al. [44, 54] who obtained values of 56.9775.07 and 61.90-64.23, respectively; Legua et al. [35] of 59.14-64.40; and Mena et al. [3] of 64.15-89.28. Regarding the maturity indexes of our Valenciana (57.73), Wonderful 1 (9.40), and Wonderful 2 (5.68) cultivars, these were similar to Mena et al. [3], who determined maturity indexes between 52.15 and 61.67 for Valenciana, and 5.19 and 29.08 for Wonderful cultivars. For other cultivars the TSS/TA ratio varied from 11.5 to 33 for Croatian [52], 5.4-37.7 and 4.8-37.7 for Italian [33, 53, 61] and 37.4-77.6 for Moroccan cultivars [62].

Taking into account the total titratable acidity and maturity index, Chace et al. [63] referred that pomegranate is appropriate for fresh market when its acidity content is lower than $1.8 \%$ and its maturity index is between 7 and 12 . Moreover, when maturity index ranges between 11 and 16, pomegranates are considered to be quite tasty. Thus, taking into account our results all cultivars studied were appropriate for fresh market and considered tasty, with exception of Parfianka, Wonderful 1 and Wonderful 2 than had higher acidity ( $>1.9 \%$ citric acid).

\section{Total monomeric anthocyanin}

The total monomeric anthocyanin contents of the nine pomegranate cultivars analyzed in the present study varied significantly among them, ranging from 43.4 (Cis 127) to $293.5 \mathrm{mg}$ Cy 3-glu/l (Wonderful 2), closely followed by CG8 (284.6 mg Cy 3-glu/l). This range was smaller than that reported by Sepúlveda et al. [64], 168-1328 mg Cy 3-glu/l, for genotypes of different regions of Chile. When comparing our results with Mena et al. [3], a similar trend was obtained, namely: Wonderful $>$ Mollar de Elche $>$ Valenciana. In generally, our results were higher than Elfalleh et al. [64] who reported values between 28.15 (Gabsi3) and 48.27 (Chetoui) mg Cy 3-glu/l for Tunisian cultivars. On contrary, the values obtained for Wonderful cultivars (254.8 and $293.5 \mathrm{mg} \mathrm{Cy} \mathrm{3-glu/l)} \mathrm{were} \mathrm{within}$ the range reported by Gil et al. [6] of $161.9-387.4 \mathrm{mg} \mathrm{Cy}$ 3 -glu/l for different juices of the same cultivar.

Anthocyanins are considered responsible for the red color of pomegranate and its arils, which is an attribute of 
quality [7]. The red color depends on the concentration and type of anthocyanins. In this order, in the present study Cis 127 cultivar showed the lowest level of anthocyanins and the juice with the lowest reddish color, as can be seen in Fig. $1 b$.

$\mathrm{pH}$ is an important factor for color expression of anthocyanins, being these compounds more stable in acidic than alkaline or neutral medium. In acidic medium, there is a shift in anthocyanins chromophores equilibrium to the flavylium cation, the most stable anthocyanin form $[60,66]$. The juices of Wonderful 1, Wonderful 2 and Katirbasi cultivars were the most reddish (Fig. 1) due to their high anthocyanin pigment contents and low $\mathrm{pH}(2.56-3.42)$. Even though CG8 presented a high anthocyanin pigment concentration, its higher $\mathrm{pH}$ (3.57) may explain its lower reddish color.

\section{Flavonoids}

The flavonoid contents of the nine cultivars studied in the present work ranged from 20.8 to $189.4 \mathrm{mg}$ QE/100 ml juice. Katirbasi and CG8 cultivars were those that had the highest flavonoid contents, whereas Parfianka, Wonderful 2, and Cis 127 the lowest values. Our range was slight higher than Orak et al. [67] who obtained values between 38.78 and $45.50 \mathrm{mg}$ QE/100 $\mathrm{ml}$ for Turkish pomegranates, taking into account the extraction yields and flavonoid contents of aqueous extracts.

\section{Hydrolyzable tannins}

Significant differences on hydrolyzable tannin contents were detected between pomegranate cultivars (Table 3), ranging from 26.0 to $325.3 \mathrm{mg} \mathrm{TAE} / 100 \mathrm{ml}$ juice. Our range was slight higher than Elfalleh et al. [47, 65] of
197-338 mg TAE/100 ml juice for Tunisian cultivars. Our Katirbasi value (325.3 mg TAE/100 ml juice) was within the range reported by Orak et al. [67] of 309-378 mg $\mathrm{TAE} / 100 \mathrm{ml}$ juice for Turkish pomegranates of the same cultivar.

Katirbasi and Parfianka had the highest values of hydrolyzable tannins, whereas Mollar de Elche and Wonderful 1 the lowest contents. Tannin content is an important factor for fruit acceptability by consumers, as it is associated with astringency [60]. In this order, Katirbasi would be the most astringent and Mollar de Elche the less. This in line with Melgarejo et al. [44] who reported that Mollar de Elche family is characterized by its sweetness, low sourness, and soft and easy to eat pith.

\section{Vitamin C}

Vitamin $\mathrm{C}$ contents in the juice of the nine cultivars studied in the present work varied between 25.6 and $110.2 \mathrm{mg}$ AA/100 ml juice for the Wonderful 2 and Katirbasi cultivars, respectively. Our values were generally higher than Ferrara et al. [53] (8.90-23.63 mg AA/100 ml juice); Mena et al. [3] (8.0-20.0 mg AA/100 ml juice); Paul and Ghosh [68] (19.8 mg AA/100 ml juice); Zarei et al. [27] (8.68-15.07 mg AA/100 g); and Tehranifar et al. [26] (9.91-20.92 mg AA/100 g), indicating that the cultivars grown in Spain presented higher vitamin $\mathrm{C}$ contents than those analyzed by the referred authors.

\section{Antioxidant activity}

\section{Total reducing capacity}

The Total reducing capacities of the juices of the nine cultivars are represented in Fig. 2a, varying from 94.7

Table 3 Anthocyanin, flavonoids, hydrolyzable tannins and vitamin C contents, as well as, antioxidant activity of juices of nine pomegranate cultivars grown in Spain

\begin{tabular}{|c|c|c|c|c|c|c|}
\hline Cultivar & $\begin{array}{l}\text { Monomeric antho- } \\
\text { cyanin pigment } \\
(\mathrm{mg} \text { Cy } 3-\mathrm{glu} / \mathrm{l})\end{array}$ & $\begin{array}{l}\text { Flavonoids } \\
(\mathrm{mg} \mathrm{QE} / 100 \mathrm{ml} \\
\text { juice) }\end{array}$ & $\begin{array}{l}\text { Hydrolyzable tannins } \\
\text { (mg TAE/100 ml } \\
\text { juice) }\end{array}$ & $\begin{array}{l}\text { Vitamin C } \\
\text { (mg AA/100 ml } \\
\text { juice) }\end{array}$ & $\begin{array}{l}\mathrm{EC}_{50} \mathrm{DPPH} \\
(\mu \mathrm{l} \text { juice } / \mathrm{ml})\end{array}$ & $\begin{array}{l}\mathrm{EC}_{50} \text { Reducing } \\
\text { power } \\
(\mu \mathrm{l} \text { juice } / \mathrm{ml})\end{array}$ \\
\hline Mollar de Elche & $116.2 \pm 5.7^{\mathrm{c}}$ & $53.0 \pm 1.6^{\mathrm{c}, \mathrm{d}}$ & $26.0 \pm 1.8^{\mathrm{c}}$ & $79.3 \pm 3.7^{\mathrm{b}, \mathrm{c}}$ & $9.78 \pm 0.13^{b}$ & $92.5 \pm 0.9^{\mathrm{a}}$ \\
\hline Valenciana & $52.8 \pm 3.8^{\mathrm{d}}$ & $52.1 \pm 7.9^{\mathrm{c}, \mathrm{d}}$ & $133.8 \pm 20.4^{\mathrm{b}, \mathrm{c}}$ & $83.4 \pm 3.7^{\mathrm{b}, \mathrm{c}}$ & $9.78 \pm 0.26^{\mathrm{a}, \mathrm{b}}$ & $21.8 \pm 1.0^{\mathrm{c}}$ \\
\hline White & $245.5 \pm 2.4^{\mathrm{b}}$ & $63.6 \pm 8.8^{\mathrm{c}}$ & $102.6 \pm 8.3^{b, c}$ & $88.8 \pm 5.2^{\mathrm{b}}$ & $6.37 \pm 0.05^{\mathrm{b}, \mathrm{c}}$ & $20.9 \pm 1.6^{\mathrm{c}}$ \\
\hline CG8 & $284.6 \pm 1.9^{\mathrm{a}}$ & $123.3 \pm 2.5^{b}$ & $121.8 \pm 4.2^{\mathrm{b}}$ & $76.3 \pm 5.5^{\mathrm{c}}$ & $7.16 \pm 0.01^{\mathrm{b}}$ & $12.6 \pm 0.2^{\mathrm{c}}$ \\
\hline Cis 127 & $43.4 \pm 8.5^{\mathrm{d}}$ & $48.6 \pm 0.3^{\mathrm{d}}$ & $114.6 \pm 22.0^{\mathrm{b}}$ & $50.7 \pm 1.0^{\mathrm{d}}$ & $7.65 \pm 0.02^{\mathrm{b}}$ & $16.8 \pm 0.1^{\mathrm{c}}$ \\
\hline Katirbasi & $256.5 \pm 0.1^{\mathrm{b}}$ & $189.4 \pm 6.0^{\mathrm{a}}$ & $325.3 \pm 15.3^{\mathrm{a}}$ & $110.2 \pm 3.7^{\mathrm{a}}$ & $4.97 \pm 0.11^{\mathrm{b}, \mathrm{c}}$ & $22.8 \pm 2.9^{\mathrm{b}, \mathrm{c}}$ \\
\hline Parfianka & $109.2 \pm 3.3^{c}$ & $20.8 \pm 1.8^{\mathrm{e}}$ & $257.0 \pm 19.3^{\mathrm{a}}$ & $17.9 \pm 0.1^{\mathrm{e}}$ & $16.62 \pm 0.11^{\mathrm{a}}$ & $52.9 \pm 0.7^{\mathrm{a}, \mathrm{b}}$ \\
\hline Wonderful 1 & $254.8 \pm 2.4^{\mathrm{b}}$ & $65.1 \pm 1.4^{\mathrm{c}}$ & $78.7 \pm 25.2^{\mathrm{b}, \mathrm{c}}$ & $39.3 \pm 3.1^{\mathrm{d}}$ & $7.59 \pm 0.03^{b}$ & $23.6 \pm 0.3^{\mathrm{b}, \mathrm{c}}$ \\
\hline Wonderful 2 & $293.5 \pm 0.6^{\mathrm{a}}$ & $47.7 \pm 1.2^{\mathrm{d}}$ & $97.9 \pm 14.4^{\mathrm{b}, \mathrm{c}}$ & $25.6 \pm 1.0^{\mathrm{e}}$ & $1.97 \pm 0.27^{\mathrm{c}}$ & $38.7 \pm 0.1^{\mathrm{a}, \mathrm{b}, \mathrm{c}}$ \\
\hline
\end{tabular}

Cy 3-glu cyanidin 3-glucoside, $Q E$ quercetin equivalent, TAE tannic acid equivalent, $A A$ ascorbic acid

Values in the same column with different letters are statistically different $(p<0.05)$ 
Fig. 2 Antioxidant activity of juice of nine pomegranate cultivars grown in Spain: Total Reducing Capacity (a), DPPH radical-scavenging activity (\%) versus concentration of juice (b) and Reducing Power (Abs $700 \mathrm{~nm}$ ) versus concentration of juice (c)
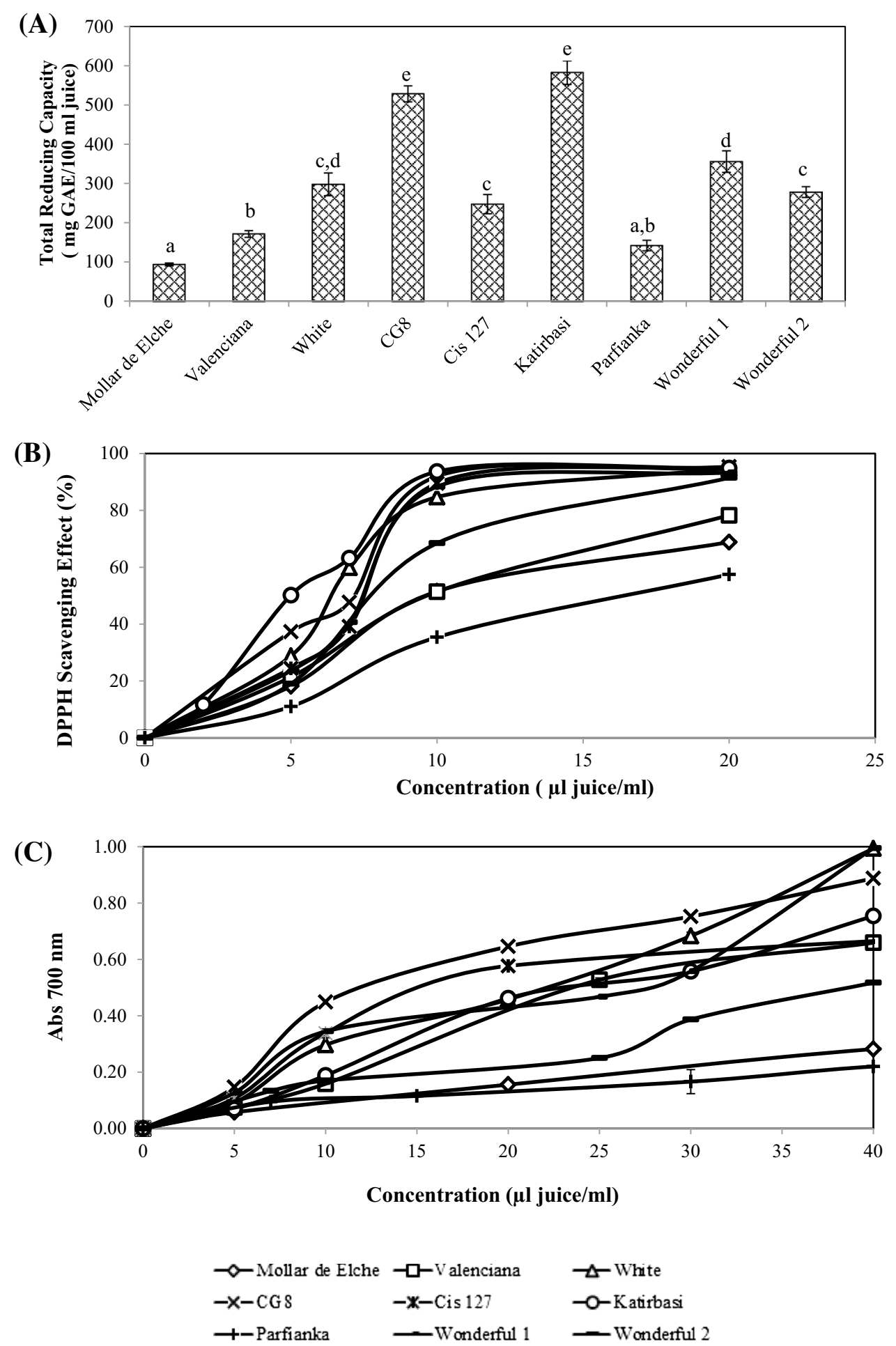

(Mollar de Elche) to 581.0 (Katirbasi) mg GAE/100 ml juice, due to the presence of antioxidants. According to Elfalleh et al. [62], pomegranate is a natural source of these compounds, namely tannins, polyphenols, flavonoids, and vitamin $\mathrm{C}$. This is in line with the present study because Katirbasi cultivar showed the highest values of flavonoids (189.4 mg QE/100 ml juice); vitamin
C (110.2 mg AA/100 ml juice) and hydrolyzable tannins (325.3 mg TAE/100 ml juice). On the contrary, Mollar de Elche was one of the cultivars with low values of flavonoids (53.0 mg QE/100 ml juice) and hydrolyzable tannins (26.0 mg TAE/100 ml juice), explaining its low phenolic content, estimated by total reducing capacity. Our range of total reducing capacity was higher than 
Ferrara et al. [33, 53] with values from 30.3 to $282.9 \mathrm{mg}$ $\mathrm{GAE} / 100 \mathrm{ml}$ of juice for Italian pomegranates; Radunić et al. [31, 52] of 198.56-294.87 mg GAE/100 ml for cultivars grown in Croatia; Ozgen et al. [29] of 124.5-207.6 mg GAE/100 ml for Turkish cultivars; and Sepúlveda et al. [64] of 67.6-128.0 mg GAE/100 ml for Chilean pomegranate genotypes. On the contrary, Tezcan et al. [69] reported higher values than ours, namely 14.4$1008.6 \mathrm{mg}$ GAE$/ 100 \mathrm{ml}$. When comparing our results with Mena et al. [3], who also studied Spanish cultivars, our value for Mollar de Elche was lower than theirs (94.7 vs. 150.0-200.0 mg GAE/100 ml), whereas for Valenciana and Wonderful cultivars our values were similar to their ranges (171.4 vs. $200.0-250.0$, and $277.8-355.4$ vs. 200.0-400.0 mg GAE/100 ml, respectively). Even though Mollar de Elche, Valenciana and White are the most known cultivars by consumers, others such as CG8 and Katirbasi, presented interesting total reducing capacities, and so antioxidant potential.

\section{DPPH (2,2-diphenyl-1-picrylhydrazyl) radical-scavenging activity}

The antioxidant activity determined by DPPH method for the nine cultivars studied in present work (Fig. 2b and Table 3) showed significant differences between them. The DPPH free radical-scavenging activity increased with juice concentration (Fig. 2b). The $\mathrm{EC}_{50}$ values ranged between 1.97 and $16.62 \mu \mathrm{l}$ juice/ml for Wonderful 2 and Parfianka cultivars, respectively (Table 3). In this order, Wonderful 2 followed by Katirbasi had the highest antioxidant potential, since they showed the lowest $\mathrm{EC}_{50}$ values. Until now, few studies have determined DPPH free radical-scavenging activity of pomegranate juice; however, Elfalleh et al. [47] for Tunisian cultivars detected $\mathrm{EC}_{50}$ values ranging from 15.98 to $23.98 \mu \mathrm{l}$ juice/ml, similar to our Parfianka, indicating lower antioxidant capacity of those cultivars.

\section{Reducing power}

Regarding reducing power, significant differences were detected among cultivars, increasing Reducing Power with juice concentration (Fig. 2c). As shown in Table 3, it can be seen that the $\mathrm{EC}_{50}$ values ranged between 12.6 and $92.5 \mu \mathrm{l}$ juice/ml for CG8 and Mollar de Elche cultivars, respectively. In this order, CG8 closely followed by Cis 127 , presented the highest Reducing Power, as they had the lowest $\mathrm{EC}_{50}$ values.

\section{Identification and quantification of phytochemicals compounds in pomegranate juices}

A total of 53 compounds of polyphenols were identified, including, 20 hydrolyzable tannins, 15 phenolic acid derivates, 12 non-colored flavonoids, four lignans, and two organics acids (Table 4). Nevertheless, only 17 compounds were detected in all of the nine cultivars. Cis 127, White, Wonderful 2, and CG8 were the cultivars with the highest number of compounds identified, whereas Valenciana and Mollar de Elche presented the lowest number of compounds. This data showed that the nine cultivars studied presented different polyphenols profiles.

As already reported in the literature, hydrolyzable tannins are the most abundant antioxidant polyphenolic compounds in pomegranate juices $[50,51]$ and include pedunculagin $(11,12,15)$, punicalin (10), punicalagin (17), HHDP glucoside (7) and ellagic acid (3, 4, 5, 6, $13,14)$. The highest number of hydrolyzable tannins was detected in CG8, Cis 127, and Wonderful 1 (17 compounds). On the contrary, Mollar de Elche and Valenciana had the lowest number of identified compounds, namely 8 and 4, respectively. Katirbasi was the cultivar that presented the highest hydrolyzable tannins content (325.3 mg TAE/100 ml juice), being detected 16 individual compounds, as well as, the highest content of ellagic acid (4.83 mg/l) (Table 5). Our range for ellagic acid $(0.69-4.83 \mathrm{mg} / \mathrm{l})$ was higher than that reported by Li et al. [70] for Chinese cultivars $(0.25-1.02 \mathrm{mg} / \mathrm{l})$, suggesting some variability in the content of this compound among pomegranate cultivars. Furthermore, NuncioJáuregui et al. [11] found higher values of derivatives of ellagic acid in sour-sweet cultivars, being Katirbasi one of these. Wu et al. [20] showed that punicalagin and ellagic acid inhibit the activity of the fatty acid synthase, having potential in the prevention and treatment of obesity. So, some pomegranate cultivars may be recommended in weight-loss diets.

Phenolic acids have two parent structures: hydroxycinnamic acid and hydroxybenzoic acid. Hydroxycinnamic acid derivatives include ferulic $(31,34)$, caffeic (33), and $p$-coumaric $(32,35)$, while hydroxybenzoic acid derivatives consist of gallic (22), vanillic $(21,27,28)$, syringic $(29,30)$, and protocatechuic $(24,26)$ acids. White and Cis 127 were the cultivars with the highest number of phenolic acids derivates identified compounds, namely 14 compounds, while Mollar de Elche, CG8, and Wonderful 1 presented 13 compounds. In the present work the gallic acid was tentatively quantified (Table 5), being Mollar de Elche and Kartibasi cultivars those that presented the highest contents, 2.67 and $2.68 \mathrm{mg} / \mathrm{l}$, respectively. 


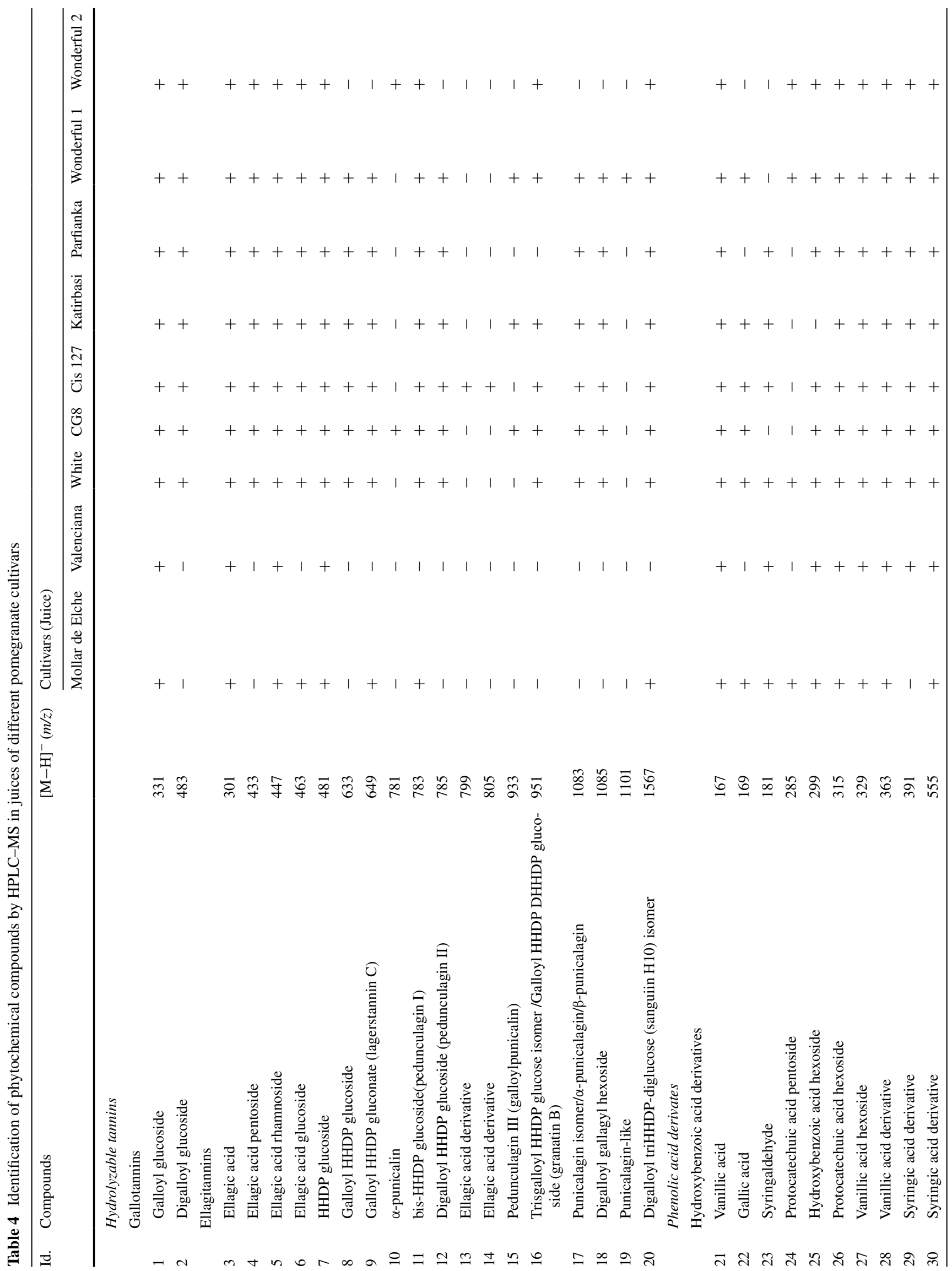




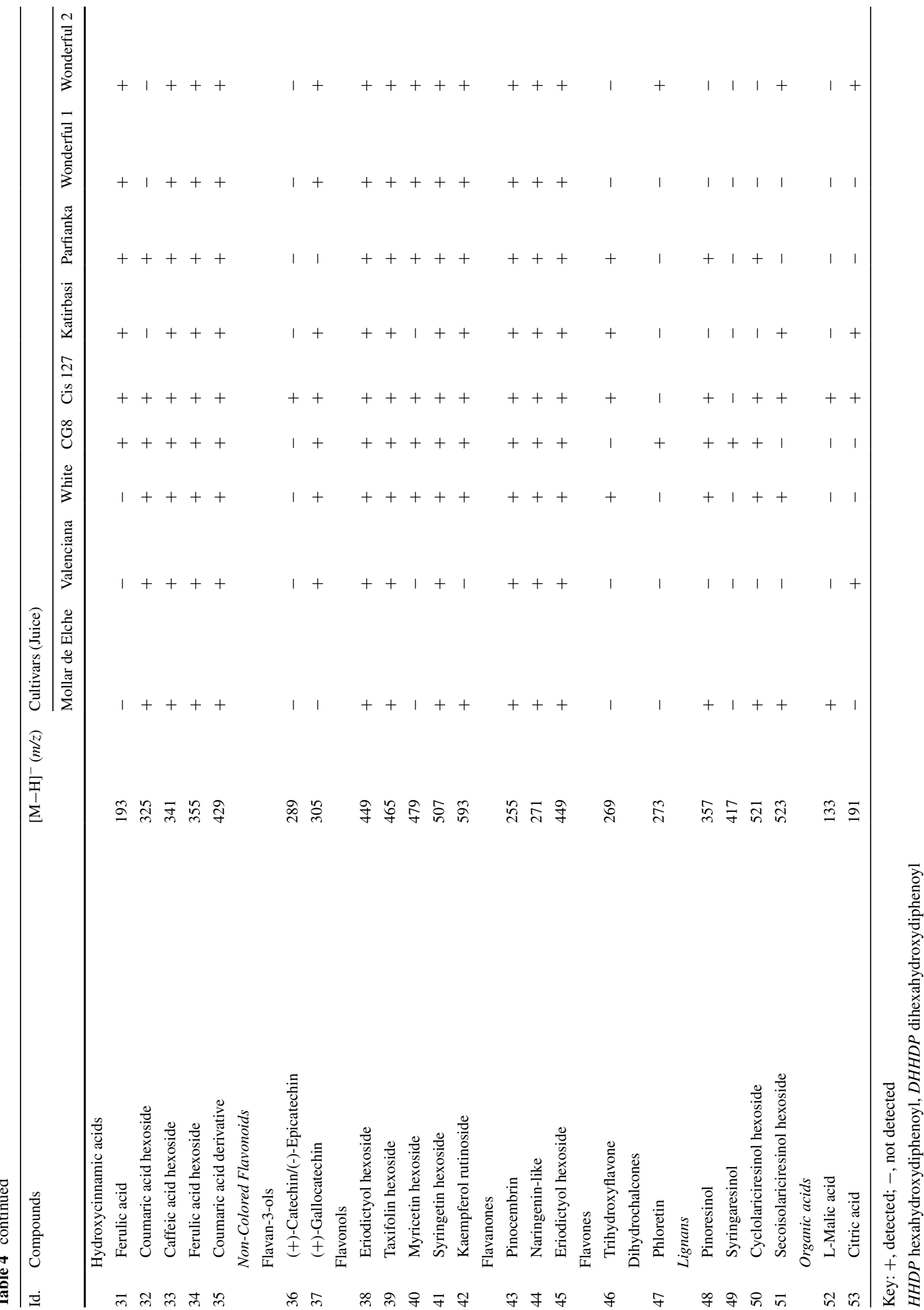


Table 5 Individual compounds analyzed by HPLC-MS in pomegranate juices (mg/l)

\begin{tabular}{llllll}
\hline Cultivars & $\begin{array}{l}\text { Ellagic } \\
\text { acid }\end{array}$ & Gallic acid & $\begin{array}{l}\text { Cyanidin-3,5-di-O-glucoside } \\
\text { chloride }\end{array}$ & $\begin{array}{l}\text { Cyanidin 3-O-glucoside } \\
\text { chloride }\end{array}$ & $\begin{array}{l}\text { Pelargonidin } \\
\text { 3- } O \text {-glucoside } \\
\text { chloride }\end{array}$ \\
\hline Mollar de Elche & 1.90 & 2.67 & 35.6 & 20.6 & 12.9 \\
Valenciana & 2.77 & $<\mathrm{DL}$ & 8.0 & 0.4 & 0.2 \\
White & 1.75 & 0.56 & 57.0 & 24.1 & 3.7 \\
CG8 & 2.14 & 0.41 & 108.3 & 12.4 & 1.4 \\
Cis 127 & 0.99 & 0.73 & 5.9 & 0.5 & $<$ DL \\
Katirbasi & 4.83 & 2.68 & 63.0 & - & 3.0 \\
Parfianka & 0.69 & $<\mathrm{DL}$ & 34.6 & 27.6 & 2.5 \\
Wonderful 1 & 1.72 & 0.19 & 54.1 & 26.2 & 2.5 \\
Wonderful 2 & 2.54 & $<\mathrm{DL}$ & 72.9 & & 2.0 \\
\hline
\end{tabular}

$D L$ detection limit

Comparing our results with Li et al. [70], who had studied 10 Chinese cultivars, higher ranges were found, namely: 0.70-15.93 mg/l.

Thirteen different flavonoids belonging to five subclasses of non-colored flavonoids (flavan-3-ols, flavonols, flavanones, flavones, and dihydrochalcones) were identified, all previously reported in pomegranate juice [50, 51]. The highest number of non-colored flavonoids compounds (11 compounds) was detected in the juice of Cis 127.

Among the lignans identified, pinoresinol (48), cyclolariciresinol hexoside (50), and secoisolariciresinol hexoside (51) were detected in five cultivars, while syringaresinol (49) was only detected in CG8. Moreover, in Valenciana and Wonderful 1 cultivars, no lignans were detected.

Regarding organic acids, citric acid (53) and L-malic acid (52) have been pointed out as the main organic acids in pomegranate juices [46]. In the present study, Mollar de Elche and Cis 127 were the only cultivars with L-malic acid, whereas, citric acid was presented in Valenciana, Cis 127, Katirbasi and Wonderful 2.

Furthermore, the pomegranate juice color is due to the presence of anthocyanins. So, in the present work the cyanidin-3,5-di- $O$-glucoside, cyanidin-3-O-glucoside and pelargonidin-3-O-glucoside chloride were quantified (Table 5). Regarding their individual concentrations, the highest value of cyanidin-3,5-di- $O$-glucoside chloride was obtained for CG8 cultivar (108.3 mg/l), while the lowest concentrations were observed for Cis 127 $(5.9 \mathrm{mg} / \mathrm{l})$ and Valenciana $(8.0 \mathrm{mg} / \mathrm{l})$. Concerning cyanidin-3-O-glucoside chloride, compound that increases the fibrinolytic potency of vascular endothelial cells and may prevent thrombus formation, the Wonderful 1 cultivar was the one with the highest content $(27.6 \mathrm{mg} / \mathrm{l})$, closely followed by Wonderful $2(26.2 \mathrm{mg} / \mathrm{l})$. Mollar de
Elche presented the highest content of pelargonidin-3-Oglucoside chloride $(12.9 \mathrm{mg} / \mathrm{l})$ that is an anthocyanin able to protect successfully membrane lipids against oxidation induced by both chemical such as AAPH (2,2'-azobis(2methylpropionamidine) dihydrochloride) radicals and physical (UVC radiation) agents [71]. For both compounds, Valenciana and Cis 127 were the cultivars that again presented the lowest concentrations, in line with the results obtained for the monomeric anthocyanin pigment contents (Table 3). Regarding the anthocyanins concentration, they follow the next order: cyanidin3,5-di-O-glucoside, cyanidin-3-O-glucoside, and pelargonidin-3-O-glucoside chloride. Similar order was reported for cultivars grown in Georgia [46]. However, this order was different than that reported for Raduníc et al. [52], who observed higher values of cyanidin-3-O-glucoside

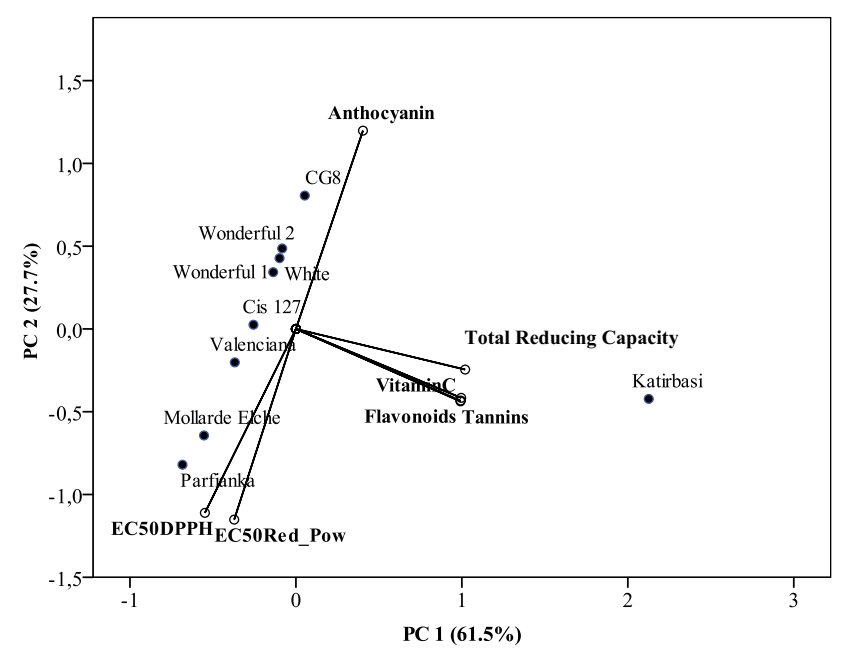

Fig. 3 Principal component analysis plot of nine pomegranate cultivars grown in Spain 
than for cyanidin-3,5-di-O-glucoside in Croatian cultivars.

\section{Principal component analysis}

Principal component analysis (PCA) was applied to find any clusters within the analyzed pomegranate cultivars. The scores of the first two principal components for the nine pomegranate cultivars are presented in Fig. 3. The first two principal components took into account $89.2 \%$ $(\mathrm{PC} 1=61.5 \%$ and $\mathrm{PC} 2=27.7 \%$, respectively $)$ of the total variation. $\mathrm{PC} 1$ was highly contributed by total reducing capacity, flavonoids, hydrolyzable tannins, and vitamin C. PC2 was mainly correlated positively to monomeric anthocyanin pigment and negatively to $\mathrm{EC}_{50}$ values of DPPH and Reducing Power assays. Katirbasi could be separated from the other cultivars, with high scores in PC1 due to its high values of total reducing capacity, hydrolyzable tannins, flavonoids, and vitamin C. Regarding other cultivars, CG8 and Wonderful 2 presented the highest monomeric anthocyanin contents, whereas Mollar de Elche and Parfianka showed the highest $\mathrm{EC}_{50}$ values of DPPH and reducing power, indicating less antioxidant activity.

\section{Conclusions}

The presented study demonstrated that different pomegranate cultivars presented different physicochemical and antioxidant properties, which are factors of great importance to characterize pomegranate cultivars with respect to their future use. Mollar de Elche presented one of the highest TSS/TA ratio in juice and the lowest seeds $\%$ in arils and hydrolyzable tannins contents (less astringent), being appropriate for fresh consumption and juice industry. On the other hand, Katirbasi cultivar presented distinctive characteristics from the other cultivars because its juice showed the highest values of flavonoids, hydrolyzable tannins, and vitamin $\mathrm{C}$, explaining its high antioxidant potential, measured by total reducing capacity, suggesting health benefits for the consumers. Even though Katirbasi presented the smallest fruits, this cultivar should be valorised by its juice chemical properties. A total of 53 polyphenols were identified, including 20 hydrolyzable tannins, 15 phenolic acid derivates, 12 non-colored flavonoids, four lignans, and two organic acids. Among the nine pomegranate cultivars' juices different compounds were detected and quantified such as ellagic acid, cyanidin-3-glucoside and pelargonidin-3-O-glucoside chloride, compounds with potential in the prevention and treatment of diseases. This study might provide valuable information on pomegranate cultivars in order to better characterize them and for developing new beverages or products where cultivars less appreciated by consumers may be added.

Acknowledgements Authors are grateful to POCTEP-Programa de Cooperação Transfronteiriça Espanha-Portugal for financial support through the Project "RED/AGROTEC - Experimentation network and transfer for development of agricultural and agro industrial sectors between Spain and Portugal" and CIMO through the Project PEst-OE/AGR/UI0690/2014 and the Foundation for Science and Technology (FCT, Portugal) and FEDER under Programme PT2020 for financial support to CIMO (UID/AGR/00690/2013).

\section{Compliance with ethical standards}

\section{Conflict of interest None.}

Compliance with ethics requirements This article does not contain any studies with human or animal subjects.

\section{References}

1. Andreu-Sevilla AJ, Signes-Pastor AJ, Carbonell-Barrachina AA (2009) La granada: producción, composición y propiedades beneficiosas para la salud. In Informe de la Universidad Miguel Hernández, Elche, Elchedigital.es, Spain

2. Holland D, Hatib K, Bar-Ya'akov I (2009) Pomegranate: botany, horticulture, breeding. Hortic Rev 35:127-191

3. Mena P, García-Viguera C, Navarro-Rico J, Moreno DA, Bartual J, Saura D, Martí N (2011) Phytochemical characterisation for industrial use of pomegranate (Punica granatum L.) cultivars grown in Spain. J Sci Food Agric 91:1893-1906

4. Akpinar-Bayizit A, Ozcan T, Yilmaz-Ersan L (2012) The therapeutic potential of pomegranate and its products for prevention of cancer. In: Georgakilas AG (ed) Cancer prevention-from mechanisms to translational benefits. InTech, Croatia

5. Department of Agriculture and Food, Western Australia, Growing pomegranates in Western Australia. http://www.agric.wa.gov. au. Accessed 29th Oct 2013

6. Gil MI, Tomás-Barberán FA, Hess-Pierce B, Holcroft DM, Kader AA (2000) Antioxidant activity of pomegranate juice and its relationship with phenolic composition and processing.' $\mathrm{J}$ Agric Food Chem 48:4581-4589

7. Hernández F, Melgarejo P, Tomás-Barberán FA, Artés F (1999) Evolution of juice anthocyanins during ripening of new selected pomegranate (Punica granatum) clones. Eur Food Res Technol 210:39-42

8. Jurenka J (2008) Therapeutic applications of pomegranate (Punica granatum L.): a review. Altern Med Rev 13:128-144

9. Legua P, Melgarejo P, Martínez M, Hernández F (2009) Evolution of anthocyanin content of four pomegranate cultivars (Punica granatum L.) during fruit development. In: Melgarejo P, Martínez-Nicolás JJ, Martínez-Tomé J (eds) Production, processing and marketing of pomegranate in the Mediterranean region: Advances in research and technology, Options Méditerranéennes: Série A. Séminaires Méditerranéens, n. 42: CIHEAM, Madrid 
10. Melgarejo P, Salazar DM, Artés F (2000) Organic acids and sugars composition of harvested pomegranate fruits. Eur Food Res Technol 211:185-190

11. Nuncio-Jáuregui N, Nowicka P, Munera-Picazo S, Hernández F, Carbonell-Barrachina AA, Wojdyło A (2015) Identification and quantification of major derivatives of ellagic acid and antioxidant properties of thinning and ripe Spanish pomegranates. J Funct Foods 12:354-364

12. Viuda-Martos M, Ruiz-Navajas Y, Fernández-López J, Sendra E, Sayas-Barberá E, Pérez-Álvarez JA (2011) Antioxidant properties of pomegranate (Punica granatum L.) bagasses obtained as co-product in the juice extraction. Food Res Int 44:1217-1223

13. Aviram M, Dornfeld L, Rosenblat M, Volkova N, Kaplan M, Coleman R, Hayek T, Presser D, Fuhrman B (2000) Pomegranate juice consumption reduces oxidative stress, atherogenic modifications to LDL, and platelet aggregation: studies in humans and in atherosclerotic apolipoprotein E-deficient mice. Am J Clin Nutr 71:1062-1076

14. Basu A, Penugonda K (2009) Pomegranate juice: a heart-healthy fruit juice. Nutr Rev 67:49-56

15. Albrecht M, Jiang W, Kumi-Diaka J, Lansky EP, Gommersall LM, Patel A, Mansel RE, Neeman I, Geldof AA, Campbell MJ (2004) Pomegranate extracts potently suppress proliferation, xenograft growth, and invasion of human prostate cancer cells. J Med Food 7:274-283

16. Lansky E, Shubert S, Neeman I (2000) Pharmacological and therapeutic properties of pomegranate. In: Melgarejo P, Martínez-Nicolás JJ, Martínez-Tomé J (eds) Production, processing and marketing of pomegranate in the Mediterranean region: Advances in research and technology. Options Méditerranéennes: Série A. Séminaires Méditerranéens; n. 42, CIHEAM, Madrid

17. Lansky EP, Newman RA (2007) Punica granatum (pomegranate) and its potential for prevention and treatment of inflammation and cancer. J Ethnopharmacol 109:177-206

18. Rahimi HR, Arastoo M, Ostad SN (2012) A comprehensive review of Punica granatum (pomegranate) properties in toxicological, pharmacological, cellular and molecular biology researches. Iran J Pharm Res 11:385-400

19. Tomás-Barberán FA (2010) Granada y salud: aspectos farmacológicos y terapéuticos de la granada. In: Moreno PM, García FH, Murcia PL (eds) Jornadas Nacionales sobre el granado: producción, economía, industrialización, alimentación y salud. SPE3, Valencia

20. Wu D, Ma X, Tian W (2013) Pomegranate husk extract, punicalagin and ellagic acid inhibit fatty acid synthase and adipogenesis of 3T3-L1 adipocyte. J Funct Foods 5:633-641

21. Maestre J, Melgarejo P, Tomás-Barberán FA, García-Viguera C (2000) New food products derived from pomegranate. In: Melgarejo P, Martínez-Nicolás JJ, Martínez-Tomé J (eds) Production, processing and marketing of pomegranate in the Mediterranean region: advances in research and technology. Options Méditerranéennes: Série A. Séminaires Méditerranéens; n. 42, CIHEAM, Madrid

22. Ordoudi SA, Mantzouridou F, Daftsiou E, Malo C, Hatzidimitriou E, Nenadis N, Tsimidou MZ (2014) Pomegranate juice functional constituents after alcoholic and acetic acid fermentation. J Funct Foods 8:161-168

23. Park JE, Kim JY, Kim J, Kim YJ, Kim MJ, Kwon SW, Kwon O (2014) Pomegranate vinegar beverage reduces visceral fat accumulation in association with AMPK activation in overweight women: a double-blind, randomized, and placebo-controlled trial. J Funct Foods 8:274-281

24. Magerramov MA, Abdulagatov AI, Azizov ND, Abdulagatov IM (2007) Effect of temperature, concentration, and pressure on the viscosity of pomegranate and pear juice concentrates. J Food Process Eng 80:476-489

25. Madrigal-Carballo S, Rodriguez G, Krueger CG, Dreher M, Reed JD (2009) Pomegranate (Punica granatum) supplements: authenticity, antioxidant and polyphenol composition. J Funct Foods 1:324-329

26. Tehranifar A, Zarei M, Nemati Z, Esfandiyari B, Vazifeshenas MR (2010) Investigation of physico-chemical properties and antioxidant activity of twenty Iranian pomegranate (Punica granatum L.) cultivars. Sci Hort 126:180-185

27. Zarei M, Azizi M, Bashiri-Sadr Z (2010) Studies on physicochemical properties and bioactive compounds of six pomegranate cultivars grown in Iran. J Food Technol 8:112-117

28. Gözlekçi Ş, Saraçoğlu O, Onursal E, Özgen M (2011) Total phenolic distribution of juice, peel, and seed extracts of four pomegranate cultivars. Pharmacogn Mag 7:161-164

29. Ozgen M, Durgaç C, Serçe S, Kaya C (2008) Chemical and antioxidant properties of pomegranate cultivars grown in the Mediterranean region of Turkey. Food Chem 111:703-706

30. Gadže J, Voća S, Čmelik Z, Mustać I, Ercisli S, Radunić M (2012) Physico-chemical characteristics of main pomegranate (Punica granatum L.) cultivars grown in Dalmatia region of Croatia. J Appl Bot Food Qual 85:202-206

31. Radunić M, Spika MJ, Ban SG, Gadže J, Lean DM (2012) Chemical composition of pomegranate (Punica granatum L.) cultivars grown in Croatia. In: Melgarejo P, Valero D (eds) II International Symposium on the Pomegranate, Options MéditerranéennesSeries A: Mediterranean Seminars, CIHEAM, Valencia

32. Legua P, Melgarejo P, Abdelmajid H, Martínez JJ, Martínez R, Ilham H, Hafida H, Hernández F (2012) Total phenols and antioxidant capacity in 10 Moroccan pomegranate varieties[. J Food Sci 71:115-120

33. Ferrara G, Giancaspro A, Mazzeo A, Giove SL, Matarrese MAS, Pacucci C, Punzi R, Trani A, Gambacorta G, Blanco A, Gadaleta A (2014) Characterization of pomegranate (Punica granatum L.) genotypes collected in Puglia region Southeastern Italy. Sci Hort 178:70-78

34. Hernández F, Legua P, Martínez M, Melgarejo P (2000) Evolution of sugars and organic acid content in three pomegranate cultivars (Punica granatum L.). In: Melgarejo P, Martínez-Nicolás JJ, Martínez-Tomé J (eds) Production, processing and marketing of pomegranate in the Mediterranean region: Advances in research and technology, Options Méditerranéennes: Série A. Séminaires Méditerranéens; $n$. 42, CIHEAM, Madrid

35. Legua $\mathrm{P}$, Melgarejo $\mathrm{P}$, Martínez JJ, Martínez R, Hernández $\mathrm{F}$ (2012) Evaluation of Spanish pomegranate juices: organic acids, sugars, and anthocyanins. Int J Food Prop 15:481-494

36. Martínez JJ, Melgarejo P, Hernández F, Salazar DM, Martínez R (2006) Seed characterisation of five new pomegranate (Punica granatum L.) varieties. Sci Hort 110:241-246

37. Vegara S, Martí N, Lorente J, Coll L, Streitenberger S, Valero M, Saura D (2014) Chemical guide parameters for Punica granatum $c v$. 'Mollar' fruit juices processed at industrial scale. Food Chem 147:203-208

38. Council Regulation (EEC) No 2092/91 of 24 June 1991 on organic production of agricultural products and indications referring thereto on agricultural products and foodstuffs

39. Meier U (2001) BBCH monograph — growth stages of mono and dicotyledonous plants. Federal Biological Research Centre for Agriculture and Forestry, Bonn

40. Melgarejo P, Salazar D (2003) Treaty of fruit production for arid and semi-arid areas: carob, pomegranate and jujube, vol II. Mundi-Prensa Libras S.A, Madrid (in Spanish)

41. Codex Alimentarius Commission (2012) Report of the 17th session of the Codex Committee on fresh fruits and vegetables. Codex Alimentarius Commission, Mexico City 
42. Dafny-Yalin M, Glazer I, Bar-Ilan I, Kerem Z, Holland D, Amir $R$ (2010) Color, sugars and organic acids composition in aril juices and peel homogenates prepared from different pomegranate accessions. J Agric Food Chem 58:4342-4352

43. Shwartz E, Glazer I, Bar-Ya'akov I, Matityahu I, Bar-Ilan I, Holland D, Amir R (2009) Changes in chemical constituents during the maturation and ripening of two commercially important pomegranate accessions. Food Chem 115:965-973

44. Melgarejo P, Calín-Sánchez A, Vázquez-Aráujo L, Hernández F, Martínez JJ, Legua P, Carbonell-Barrachina AA (2011) Volatile composition of pomegranates from 9 Spanish cultivars using headspace solid phase microextraction. J Food Sci 76:114-120

45. Bchir B, Besbes S, Karoui R, Attia H, Paquot M, Blecker C (2012) Effect of air-drying conditions on physico-chemical properties of osmotically pre-treated pomegranate seeds. Food Bioprocess Technol 5:1840-1852

46. Rajasekar D, Akoh CC, Martino KG, MacLean DD (2012) Physico-chemical characteristics of juice extracted by blender and mechanical press from pomegranate cultivars grown in Georgia. Food Chem 133:1383-1393

47. Elfalleh W, Hannachi H, Tlili N, Yahia Y, Nasri N, Ferchichi A (2012) Total phenolic contents and antioxidant activities of pomegranate peel, seed, leaf and flower. J Med Plants Res 6:4724-4730

48. Falcão AP, Chaves ES, Kuskoski EM, Fett R, Falcão LD, Bordignon-Luiz MT (2007) Total polyphenol index, total anthocyanins and antioxidant activity of a model system of grape jelly. Ciênc Tecnol Aliment 27:637-642

49. Delgado T, Malheiro R, Pereira JA, Ramalhosa E (2010) Hazelnut (Corylus avellana L.) kernels as a source of antioxidants and their potential in relation to other nuts. Ind Crops Prod 32:621-626

50. Mena P, Calani L, Dall'Asta C, Galaverna G, García-Viguera C, Bruni R, Crozier A, Del Rio D (2012) Rapid and comprehensive evaluation of (Poly)phenolic compounds in pomegranate (Punica granatum L.) juice by UHPLC-MS. Molecules 17:14821-14840

51. Calani L, Beghè D, Mena $\mathrm{P}$, Del Rio D, Bruni R, Fabbri A, Dall'Asta C, Galaverna G (2013) Ultra-HPLC-MSn (Poly)phenolic profiling and chemometric analysis of juices from ancient Punica granatum L. Cultivars: a nontargeted approach!. J Agric Food Chem 61:5600-5609

52. Raduníc M, Špika MJ, Ban SG, Gadze J, Diáz-Pérez JC, MacLean D (2015) Physical and chemical properties of pomegranate fruit accessions from Croatia. Food Chem 177:53-60

53. Ferrara G, Cavoski I, Pacifico A, Tedone L, Mondelli D (2011) Morpho-pomological and chemical characterization of pomegranate (Punica granatum L.) genotypes in Apulia region, Southeastern Italy. Sci Hort 130:599-606

54. Melgarejo P, Sánchez M, Hernández F, Martínez JJ, Amorós A (2012) Parameters for determining the hardness and pleasantness of pomegranates (Punica granatum L.). In: Melgarejo P, Martínez-Nicolás JJ, Martínez-Tomé J (eds) Production, processing and marketing of pomegranate in the Mediterranean region: advances in research and technology, Options Méditerranéennes: Série A. Séminaires Méditerranéens; n. 42: CIHEAM, Madrid

55. FDA acidified and low-acid canned foods-approximate $\mathrm{pH}$ of foods and food products. U.S. Food and Drug Administration www.cfsan.fda.gov. Accessed 29th Oct 2013
56. Melgarejo-Sánchez P, Martínez JJ, Legua P, Martínez R, Hernández F, Melgarejo P (2015) Quality, antioxidant activity and total phenols of six Spanish pomegranates clones. Sci Hort 182:65-72

57. Opara LU, Al-Ani MR, Al-Shuaibi YS (2009) Physico-chemical properties, vitamin $\mathrm{C}$ content, and antimicrobial properties of pomegranate fruit (Punica granatum L.). Food Bioprocess Tech 2:315-321

58. Mars M, Melgarejo P, Amorós A, Martínez R (1997) Pomegranate descriptors. In: Instituto Agronómico Mediterráneo de Zaragoza (IAMZ) (ed) Collaborative Working Group on Underutilized Fruit Crops in the Mediterranean Region, CIHEAM, Zaragoza

59. De Palma L, Novello V (1995) II melograno: attualitá di una coltura antica. Rivista di Frutticoltura 11:45-49

60. Pavez IAC (2011) Caracterización física, química y sensorial de frutos de granado $c v$. Wonderful provenientes de tres regiones de Chile, Final course work. Universidad de Chile, Facultad de Ciencias Agronómicas, Santiago do Chile

61. Cristofori V, Caruso D, Latini G, Dell'Agli M, Cammilli C, Rugini E, Bignami C, Muleo R (2011) Fruit quality of Italian pomegranate (Punica granatum L.) autochthonous varieties. Eur Food Res Technol 232:397-403

62. Martínez JJ, Hernández F, Abdelmajid H, Legua P, Martínez R, Amine AE, Melgarejo P (2012) Physico-chemical characterization of six pomegranate cultivars from Morocco: processing and fresh market aptitudes. Sci Hort 140:100-106

63. Chace EM, Church CG, Poore HD (1930) The Wonderful variety of pomegranate: composition, commercial maturity, and byproducts. In: United States Department of Agriculture (ed), Circular No 98, U.S. Government Printing Office, Washington

64. Sepúlveda E, Sáenz C, Peña A, Robert P, Bartolomé B, GómezCordovés C (2010) Influence of the genotype on the anthocyanin composition, antioxidant capacity and color of Chilean pomegranate (Punica granatum L.) juices. Chil. J Agric Res 70:50-57

65. Elfalleh W, Yahia Y, Ferchichi A (2012) Main pomegranate phytochemicals and their contribution to the antioxidant potencies of pomegranate juice. In: Melgarejo P, Valero D (eds) II International Symposium on the pomegranate, Options Méditerranéennes-Series A: Mediterranean Seminars. CIHEAM, Madrid

66. Hirth M, Leiter A, Beck SM, Schuchmann HP (2014) Effect of extrusion cooking process parameters on the retention of bilberry anthocyanins in starch based food. J Food Eng 125:139-146

67. Orak HH, Yagar H, Isbilir SS (2012) Comparison of antioxidant activities of juice, peel, and seed of pomegranate (Punica granatum L.) and inter-relationships with total phenolic, tannin, anthocyanin, and flavonoid contents. Food Sci Biotechnol 21:373-387

68. Paul R, Ghosh U (2012) Effect of thermal treatment on ascorbic acid content of pomegranate juice. IJBT 11:309-313

69. Tezcan F, Gültekin-Özgüven M, Diken T, Özçelik B, Erim FB (2009) Antioxidant activity and total phenolic, organic acid and sugar content in commercial pomegranate juices. Food Chem 115:873-877

70. Li X, Wasila H, Liu L, Yuan T, Gao Z, Zhao B, Ahmad I (2015) Physicochemical characteristics, polyphenol compositions and antioxidant potential of pomegranate juices from 10 Chinese cultivars and the environmental factors analysis. Food Chem 175:575-584

71. Bonarska-Kujawa D, Pruchnik H, Kleszczyńska H (2012) Interaction of selected anthocyanins with erythrocytes and liposome membranes. Cell Mol Biol Lett 17:289-308 